\title{
Actividad antibacteriana de la clara de huevo de la tortuga marina Lepidochelys olivacea
}

\author{
Antibactericidal activity of the egg white of sea turtle Lepidochelys olivacea
}

\author{
Marcela López-Hurtado¹, María I. Castro-González² y Fernando M. Guerra-Infante ${ }^{1}$
}

\begin{abstract}
${ }^{1}$ Laboratorio de Virología, Departamento de Infectología del Instituto Nacional de Perinatología, Montes Urales 800, Col. Lomas Virreyes C.P. 11000, México D.F., México. fguerra_96@yahoo.com

${ }^{2}$ Departamento de Nutrición Animal, Instituto Nacional de Ciencias Médicas y Nutrición Salvador Zubirán, Vasco de Quiroga 15, Tlalpan. C.P. 14000, México D.F., México
\end{abstract}

\begin{abstract}
Of the proteins present in the egg albumin, ovalbumin, ovotransferrin and lysozyme have the most important bactericidal properties. However, such properties have not been reported for egg albumen of the sea turtle Lepidochelys olivacea. The objective of this study was to determine the bactericidal activity of egg white of L. olivacea at different concentrations. The results showed both a bactericidal effect on Gram-positive bacteria (Staphylococcus aureus, Staphylococcus saprophyticus and Micrococcus luteus) and Gram-negative bacteria (Klebsiella pneumoniae), as well as a proliferative effect on Gram-positive bacteria (S. aureus, Staphylococcus epidermidis and M. Iuteus) and Gram-negative (Escherichia coli, K. pneumoniae and Pasteurella multocida).
\end{abstract}

Key words: Reptile, Gram positive bacteria, Gram negative bacteria

\section{INTRODUCCIÓN}

La clara o albúmina del huevo está compuesta básicamente por agua (88\%) y proteínas (cerca del 12\%). La proteína más importante, en términos cuantitativos es la ovoalbúmina (54\%) y en menor proporción: ovotransferrina, ovomucoide, ovomucina, lisozima, avidina, cistatina y ovostatina. Además de la protección física de la cáscara, los huevos disponen de una protección química que actúa frente a las bacterias y sus moléculas bacteriolíticas. De las proteínas mencionadas, la ovoalbúmina, la ovotransferrina y la lisozima tienen las propiedades antibacterianas más importantes, entre otras. La lisozima, puede actuar como agente bacteriolítico hidrolizando la unión beta-1-4 entre el ácido Nacetilmuramínico y la $\mathrm{N}$-acetilglucosamina de la mureína. La ovotransferrina, priva a las bacterias de hierro; la cistatina, ovomucoides, ovoinhibidores y ovoestatina (ovomacroglobulina) inhiben la actividad de las proteasas bacterianas y la avidina se une a la vitamina biotina para disminuir la disponibilidad de ésta y evitar el crecimiento bacteriano (Sellier et al. 2007). Por estas propiedades antibacterianas la clara de huevo no sería considerada útil para la producción de medios de cultivo artificiales y crecimiento de las bacterias. Se ha descrito que la albúmina de huevo de aves, posee capacidad antibacteriana contra algunos microorganismos Gram positivos y Gram negativos (Wellman-Labadie et al. 2008).
Lepidochelys olivacea es la especie de tortuga marina de mayor distribución geográfica que anida de junio a diciembre a lo largo de las costas del Caribe, Golfo de México y el Pacífico mexicano. Además, normalmente más de 100.000 hembras arriban a la costa para depositar sus huevos en las playas, con una alta mortalidad de huevos en diferentes etapas de desarrollo (Márquez et al. 1989). Un estudio completo de las características del huevo de esta especie permitiría un mejor aprovechamiento de éste, además de contribuir al conocimiento de la especie.

Hasta la fecha no hay reportes suficientes en la literatura sobre el efecto antibacteriano de los componentes del huevo de Lepidochelys olivacea por lo que el objetivo del presente estudio fue describir la actividad antibacteriana de la clara de huevo de esta tortuga contra algunas bacterias Gram positivas y negativas.

\section{Material Y MÉTODOS}

Las muestras de la clara de huevo liofilizadas fueron proporcionadas por el 'Laboratorio de Geoquímica y Contaminación Costera del Instituto de Ciencias del Mar y Limnología de la Universidad Nacional Autónoma de México', colectados durante la arribazón del 2005, en La Escobilla, Oaxaca, México. 
Para el ensayo de la capacidad bactericida se analizó un 'pool' de 10 muestras (de un total de 25) de clara de huevo no eclosionado de Lepidochelys olivacea. De cada muestra se obtuvo una submuestra $0,1 \mathrm{~g}$ de clara liofilizada, a la cual se le adicionó $10 \mathrm{ml}$ de solución salina balanceada de Hank (SSBH) agitando en un vórtex hasta disolver y evitando la formación de espuma. Posteriormente el preparado se filtró a través de una membrana de $0,22 \mu \mathrm{m}$. Se hicieron alícuotas de $1 \mathrm{ml}$ y congeladas a $-70^{\circ} \mathrm{C}$ hasta el momento de su uso. A una alícuota se le determinó la concentración de proteínas por el micrométodo de Bradford (Kruger 1994).

Para el cultivo se trabajó con ocho tipos diferentes de bacterias, de las cuales tres, Escherichia coli, Staphylococcus epidermidis, y Staphylococcus saprophyticus fueron obtenidas del 'Instituto Nacional de Perinatología’ por medio de muestras clínicas de individuos colonizados y las otras cinco, Staphylococcus aureus 25923, Klebsiella pneumoniae 4352, Pasteurella multocida 11030, Micrococcus luteus 9341 y Staphylococcus hyicus 49545, se obtuvieron de cepas tipo en la colección de la 'American Type Culture Collection'(ATCC).

Las cepas bacterianas se sembraron en el medio solido de Luria-Bertani (LB), incubadas por $24 \mathrm{~h}$ a $37^{\circ} \mathrm{C}$. Posteriormente, las bacterias se recuperaron en el medio líquido BHI (Infusión cerebro- corazón) y centrifugadas a $3500 \mathrm{rpm}$ por $10 \mathrm{~min}$, eliminando el sobrenadante. El botón celular se ajustó a $12 \times 10^{8}$ bacterias $\mathrm{ml}^{-1}$ de acuerdo al tubo 4 del nefelómetro de McFarland en medio BHI. Posteriormente se hicieron alícuotas de $1 \mathrm{ml}$ con solución criopreservadora (medio BHI suplementado con glicerol al $10 \%$ ) y se congelaron a $-70^{\circ} \mathrm{C}$ hasta el momento de su uso.

El ensayo de capacidad antibacteriana se llevó a cabo de acuerdo a la técnica de Stevens et al. 1991. Para observar el efecto de la clara de huevo sobre las diferentes bacterias, a 96 pozos de una microplaca de fondo plano (24 pozos para cada concentración de bacterias) se agregaron $50 \mu \mathrm{l}$ de la suspensión bacteriana para dar una concentración de 0,$5 ; 2$; 3,5 y 5 x $10^{6}$ bacterias pozo $^{-1}$, enseguida se les adicionó $50 \mu \mathrm{l}$ de las diferentes concentraciones de clara de huevo de tortuga (5, 25 y 50 $\mu \mathrm{g})$ y $50 \mu \mathrm{l}$ del medio RPMI-1640 ${ }^{\mathrm{TM}}$ suplementado con SFT al 5\%. Cada concentración de clara de huevo se analizó por sextuplicado, en tres experimentos diferentes para cada microorganismo. En seguida se incubaron las microplacas por $90 \mathrm{~min}$ a $37^{\circ} \mathrm{C}$ y $5 \%$ de $\mathrm{CO}_{2}$. Pasado el

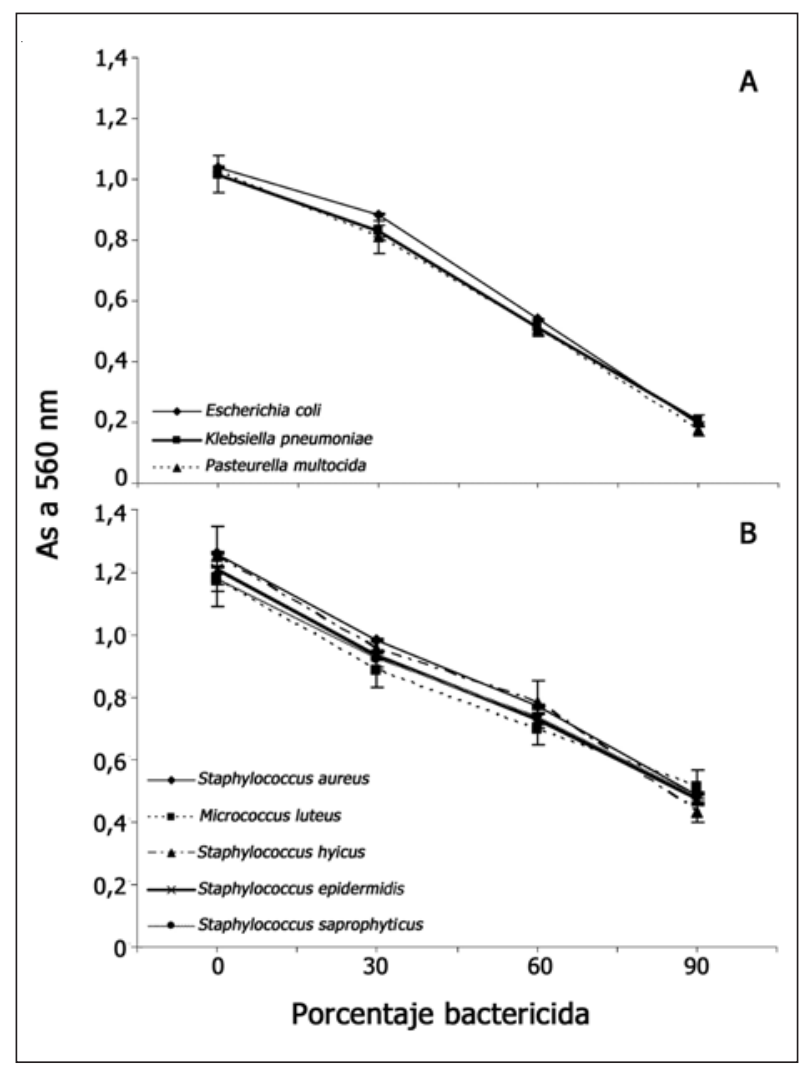

Figura 1. Curva estándar de actividad bactericida, A) bacterias Gram negativas, B) Gram positivas en ausencia de la clara de huevo de la tortuga marina Lepidochelys olivacea / Standard curve of bactericidal activity, A) Gram-negative and B)Grampositive bacteria in the absence of the egg white of marine turtle Lepidochelys olivacea

tiempo de incubación, tanto a los pozos de la microplaca de la curva estándar (bacterias incubadas sin clara de huevo de tortuga) como a los pozos de la microplaca con clara de huevo se les añadieron $50 \mu \mathrm{l}$ de 3-[4,5dimethylthiazol-2-yl]-2-,5-diphenyltetrazolium bromide (MTT) a una concentración de $2 \mathrm{mg} \mathrm{ml}^{-1}$. Las microplacas se incubaron nuevamente a temperatura ambiente por 10 min y se centrifugaron a $3500 \mathrm{rpm}$ durante $10 \mathrm{~min}$, el sobrenadante se eliminó por decantación. A cada pozo de ambas microplacas se adicionaron $150 \mu \mathrm{l}$ de alcohol isopropílico hasta disolver los cristales de formazán, en seguida se agregaron $50 \mu \mathrm{l}$ de PBS para leer la placa a 560 $\mathrm{nm}$ de longitud de onda. De cada microorganismo se obtuvo una curva estandar para conocer el grado de reducción del MTT (Fig. 1). El porcentaje de actividad bactericida se determinó con la siguiente fórmula:

$\underset{\text { bactericida }}{\% \text { actividad }}=\left[1-\left(\frac{\text { As con clara de huevo }- \text { As al } 90 \% \text { actividad bactericida }}{\text { As al } 0 \% \text { actividad bactericida }- \text { As al } 90 \% \text { actividad bactericida }}\right)\right] \cdot 90$ 
donde As es el valor de absorbancia a la longitud de onda de $560 \mathrm{~nm}$

Las comparaciones entre los porcentajes de actividad antibacteriana y proliferativa con respecto a los testigos (bacterias sin clara de huevo) fueron realizadas con el análisis estadístico no paramétrico de U Mann-Withney, y se consideró un resultado significativo cuando $P<$ 0,05 .

\section{RESUltados Y DiscusióN}

La actividad antibacteriana de la clara de huevo se observó solamente en bacterias Gram positivas, tales como $S$. saprophyticus, S. aureus, S. hyicus y M. luteus (Tabla 1). Sin embargo, en $S$. aureus no se obtuvo efecto bactericida a una concentración de $50 \mu \mathrm{g}$ de clara de huevo. Para $S$. hyicus el efecto antibacteriano solo se presentó cuando se utilizó $5 \mu$ g de la clara, mientras que para M. luteus el efecto antibacteriano fue significativo solo a concentraciones de $50 \mu \mathrm{g}$ (Tabla 1).

No se observó un efecto antibacteriano de la clara de huevo sobre las bacterias Gram negativas, pero en $E$. coli si se observó un efecto de proliferación bacteriana importante y significativo, con un 13,9\%, 27,6\% y 25,2\% de proliferación a las concentraciones empleadas respectivamente (Tabla 1). Este efecto se observó también con P. multocida, mientras que para $K$. pneumoniae la actividad proliferativa fue menor y sólo se obtuvo a las concentraciones de 25 y $50 \mu$ g (Tabla 1)

Los estudios sobre la actividad antibacteriana de los diversos componentes de la clara de huevo se han llevado a cabo en varias especies de aves, pero pocos estudios se han realizado con huevos de tortuga (Sellier et al. 2007). De cuatro diferentes especies de tortugas solo a tres (Trionyx sinensus, Amyda cartilagenea y Chelonya mydas) se les ha demostrado la presencia de lisozima (Thammasirirak et al. 2006). Un caso especial es para la tortuga marina Caretta caretta que se ha reportado la carencia de lisozima, pero cuenta con una pequeña proteína catiónica que es similar a la $\beta$-defensina de los vertebrados (Chattopadhyay et al. 2006). Sin embargo, en la tortuga marina Lepidochelys olivacea no hay investigaciones previas que determinen la presencia de lisozima.

\footnotetext{
Tabla 1. Porcentaje de actividad antibacteriana y proliferativa (entre paréntesis) de la clara de huevo de la tortuga marina Lepidochelys olivacea sobre bacterias Gram positivas y negativas / Percentage of bactericidal and proliferative (between parentheses) activity of the egg white of marine turtle Lepidochelys olivacea on Gram positive and negative bacteria
}

Microorganismos $\left(5 \times 10^{6}\right.$ bacterias $\left.\mathrm{ml}^{-1}\right)$
Concentración de la clara de huevo $(\mu \mathrm{g})$

$5 \quad 25 \quad 50$

\begin{tabular}{lccc}
\hline Staphylococcus aureus & $3,5^{*}(0)$ & $6^{*}(0)$ & $0\left(4,5^{*}\right)$ \\
Staphylococcus epidermidis & $0(7)$ & $3(0)$ & $0\left(20^{*}\right)$ \\
Staphylococcus saprophyticus & $7(0)$ & $10^{*}(0)$ & $17 *(0)$ \\
Staphylococcus hyicus & $4,7(0)$ & $0,7(0)$ & $0(2,3)$ \\
Micrococcus luteus & $0(12 *)$ & $0\left(25,5^{*}\right)$ & $7,5^{*}(0)$ \\
Escherichia coli & $0(13,9 *)$ & $0(27,6)$ & $0\left(25,2^{*}\right)$ \\
Klebsiella pneumoniae & $1,3^{*}(0)$ & $0\left(1,3^{*}\right)$ & $0\left(4,1^{*}\right)$ \\
Pasteurella multocida & $0\left(4,5^{*}\right)$ & $0\left(6,5^{*}\right)$ & $0\left(12,8^{*}\right)$ \\
\hline
\end{tabular}

*Indica diferencia significativa $P<0,05$ 
Thammasirirak et al. (2006) han reportado que el huevo de tortuga marina Chelonidae mydas tiene una lisozima con una fuerte actividad bactericida contra Gram positivas pero no para Gram negativas y una mayor actividad lítica observada en $M$. luteus, mientras que para $S$. aureus y $S$. epidermidis esta actividad fue escasa. También se ha observado nula actividad lítica sobre bacterias como $E$. coli y K. pneumoniae. Estos resultados son similares a los obtenidos en este estudio empleando la clara de huevo de Lepidochelys olivacea que resultó con una mayor actividad antibacteriana sobre Gram positivas y un efecto nulo sobre Gram negativas. Sin embargo, a diferencia de lo descrito por Thammasiriak et al. (2006), si se observó un efecto lítico mayor sobre $S$. saprophyticus que sobre $S$. aureus y $S$. epidermidis ocurriendo el efecto antibacteriano a bajas concentraciones de clara de huevo. En $M$. luteus el efecto solo se observó cuando fue mayor la concentración de la clara de huevo (Tabla 1).

Probablemente las diferencias obtenidas en este estudio (en cuanto al efecto antibacteriano y proliferativo) podrían explicarse porque la clara de huevo está formada por varias proteínas, unas con actividades antibacterianas y otras con actividades promotoras del crecimiento, causando un efecto dual, en que a ciertas concentraciones se inhibe el crecimiento bacteriano mientras que a otras concentraciones se induce el crecimiento. Esta hipótesis es corroborada por los resultados de Thammasirirak et al. (2006), quienes describen que utilizando $4 \mu \mathrm{g} \mathrm{ml}^{-1}$ de lisozima se observó el mayor efecto bactericida sobre $M$. luteus y en este estudio $5 \mu \mathrm{g}$ de la clara de huevo, tuvieron un efecto sobre $S$. aureus pero no sobre $M$. luteus. Al aumentar la concentración de clara a $50 \mu \mathrm{g}$, no tuvo efecto sobre S. aureus pero si en M. luteus.

Chijiiwa et al. (2006) indicaron que la lisozima de huevo de tortugas marinas como Chelonia mydas tiene un débil efecto antibacteriano sobre $M$. luteus, mientras que Thammasiriak et al. (2006) no detectaron actividad de la lisozima sobre bacterias Gram negativas, lo cual es similar a lo encontrado en el presente estudio. La ausencia de actividad de la lisozima en la clara de huevo de Lepidochelys olivacea puede ser debido a la baja concentración de mureína en la pared celular de las bacterias Gram negativas. Sin embargo, en tortugas de agua dulce, los componentes del huevo muestran un importante efecto antibacteriano sobre Vibrio cholerae (Thammasiriak et al. 2006). Otros estudios realizados con clara de huevo de gallina (Sangwei et al. 2003, Clavijo et al. 2006) reportaron que la lisozima no es capaz de penetrar la membrana externa de las bacterias Gram negativas, y que estas bacterias tienen un gen YafD que les confiere resistencia a la actividad de la albúmina de huevo. Posiblemente esto pueda ser aplicado para el caso de la albúmina del huevo de tortuga, aunque la confirmación de esto requiere de otros estudios.

Los resultados obtenidos en este trabajo podrían sugerir otras hipótesis para poner a prueba, por ejemplo: a) que él o los compuestos antibacterianos de la clara de huevo de la tortuga marina son diferentes a los de las tortugas de agua dulce y b) que la especificidad de las sustancias antibacterianas del huevo de tortuga marina sea sobre bacterias Gram positivas.

Las cualidades antibacterianas que presenta la clara de huevo de tortuga marina promueven el uso eficiente y adecuado en el campo de la biología de la especie y en el enriquecimiento de medios microbiológicos para algunas especies de bacterias.

\section{Agradecimientos}

Los autores agradecen al Dr. Federico Paez por su aporte de los huevos de tortuga bajo el permiso SGP/DGVS No. 06195.

\section{LITERATURA CITADA}

Clavijo R, C Loui, G Andersen, L Riley \& S Lu. 2006. Identification of genes associated with survival of Salmonella enterica Serovar Enteritidis in chicken egg albumen. Applied and Enviromental Microbiology 72: 10551064.

Chattopadhyay S, N Sinha, S Banerjee, D Roy, D Chattopadhyay \& S Roy. 2006. Small cationic protein from a marine turtle has $\beta$-defensin-like fold and antibacterial and antiviral activity. Proteins: Structure, Function, and Bioinformatics 64: 524-531.

Chijiiwa Y, S Kawamura, T Torikata \& T Araki. 2006. Amino acid sequence and activity of green turtle (Chelonia mydas) lysozyme. The Protein Journal 25: 336-344.

Kruger N. 1994. The Bradford method for protein quantitation. Methods in Molecular Biology 32: 9-15.

Márquez R, A Villanueva, C Peñaflores \& D Ríos. 1989. Situación actual y recomendaciones para el manejo de las tortugas marinas de la costa occidental mexicana, en especial la tortuga golfina Lepidochelys olivacea. Ciencia Pesquera 3: 83-91.

Sangwei L, B Killoran \& L Riley. 2003. Association of Salmonella enterica Serovar Enteritidis YafD with resistence to chicken egg albumen. Infection and Immunity 71: 67346741. 
Sellier N, M Vidal, F Baron, J Michel, J Gautron, M Protais, C Beaumont, M Gautier \& Y Nys. 2007. Estimations of repeatability and heritability of egg albumen antimicrobial activity and of lysozyme and ovotransferrin concentrations. British Poultry Science 48(5): 559-566.

Stevens G, E Kehrli \& C Canning. 1991. A colorimetric assay for quantitating bovine neutrophil bacteriocidal activity. Veterinary Immunology and Immunopathology 28: 45-56.

Thammasirirak S, P Ponkham, S Preecharram, R Khanchanuan, $P$ Phonyothee, S Daduang, Ch Srisomsap, T Araki \& J Svasti. 2006. Purification, characterization and comparison of reptile lysozymes. Comparative Biochemistry and Physiology C 143: 209217.

Wallace P, P Sotherland, T Santidrian, S Bouchard, D Reina, R Spotila \& V Paladino. 2006. Egg components, egg size, and hatchling size in leatherback turtles. Comparative Biochemistry and Physiology A 145: 524532.

Wellman L, J Picman \& M Hincke. 2008. Comparative antibacterial activity of avian egg white protein extracts. British Poultry Science 49(2): 125-132.

Recibido el 27 de octubre de 2009 y aceptado el 26 de abril de 2010 